\title{
Decentralisation, Privatisation and Changes in the Financing of Education in Slovenia: Greater Opportunities for Citizens?
}

\author{
UDK: $378(497.4) 336.1$ \\ Stanka Setnikar Cankar \\ University of Ljubljana, Faculty of Administration \\ stanka.setnikar-cankar@fu.uni-lj.si
}

\begin{abstract}
This paper has been conducted to explore the major issues and problems in higher education regarding the decentralisation, privatization, accreditation and public financing processes in Slovenia. There is significant political pressure supporting the idea that if Slovenia has regions they should be as busy as possible. The real danger is that the introduction of small regions and 7-10 universities will only strengthen centralisation.
\end{abstract}

\begin{abstract}
Slovenian public expenditure on education has generally been relatively high. However, in recent years the proportion of annual GDP spent on higher education has decreased. There is a need for student protection and regulation. For many public and private universities, however, accreditation is mainly seen as an opportunity to strengthen their image by demonstrating their quality.
\end{abstract}

Key words: higher education, privatisation, financing, Slovenia.

\section{Introduction}

The recent history of higher education in Slovenia has been marked by amendments to higher education legislation, the introduction of a new, integrated system of financing, the Bologna reform for study programmes, and the foundation of private institutions of higher education.

This paper acknowledges the fact that Slovenian higher education institutions are not yet of the same quality as the best European universities. This is one reason for which changes to higher education in Slovenia are urgently needed, since improving the quality can significantly improve Slovenia's success at the international level. It also means that a debate on the future development of higher education in Slovenia must be one of the central development issues. One does not wish to waste time and space at this point describing and 
Stanka Setnikar Cankar

Decentralisation, Privatisation and Changes in the Financing of Education in Slovenia: Greater Opportunities for Citizens?

assessing past decisions that have led to the current state of affairs. The future development of higher education in Slovenia is very important, given the backdrop of globalisation and the increasing market orientation of the European Union.

For Slovenes, it is difficult to reconcile ourselves to the fact that our ranking of 40th out of 65 countries on the IMD ranking is so poor that poor performers such as Bulgaria are just behind us with Colombia and Portugal just ahead of us. We have been around that point for ten years now, since the IMD began carrying out this measure of competitiveness, while Lithuania, the Czech Republic and Estonia remain a long way ahead of us, in 31st, 32nd, and 22 nd respectively. Among countries with populations of fewer than 20 million Slovenia occupies the penultimate position, just ahead of Croatia, and well behind the Slovaks and Czechs (Kos, 2008).

We consider higher education to be such an important part of the public sector for society and its competitiveness, as well as for individuals, that decision-makers have to reach a consensus on the basic systemic conditions for its future development.

Decisions on the type and duration of studies have long-term consequences that will determine subsequent opportunities for the individual on the job market. Knowledge and skills acquisition and their application, however, are not simply private goods. The level of education, its structure, and applicability have a decisive effect on domestic product and also represent a public good of major importance. It is probably not an exaggeration to write that they represent the major elements on which a country with scarce material resources must build its development and growth. The systemic conditions required for a high quality higher education system to function in Slovenia are therefore decisive, and the responsibility of each government for ensuring their provision is very great.

\subsection{National Higher Education Programme of the Republic of Slovenia 2007-2010}

The European higher education area has been marked over the current decade by the reform processes launched by the Bologna Declaration and the Lisbon Strategy. The Bologna Declaration makes a commitment to creating a common higher education space by 2010 , while with the Lisbon Strategy the European Union set out the objective of becoming the most competitive and 
dynamic knowledge-based economy in the world, with full employment and economic and social cohesion. It lays down a commitment to ensuring higher economic growth and increasing employment, and one of the five main strategies to achieve its aims is greater investment in education, schools, sciences, research and development.

The two documents together with the Slovenian Development Strategy, adopted by the Government on 23 June 2005, lay down the basis on which the National Programme of Higher Education for 2007-2010 is based.

The key strategies and objectives for higher education development until 2010 as set out in the national programmes are as follows:

- Increase the number of higher education institutions in Slovenia and achieve better regional coverage with individual units or programmes in all Slovenian regions, with a target of 7 to 10 universities or colleges and innovation centres in Slovenia.

- In line with current financial trends, increase funds for higher education training and research work, where the target is a total of $5 \%$ GDP, $2.3 \%$ of which will come from the budget (1\% research, $1.3 \%$ pedagogical work) and $2.7 \%$ from other sources ( $2 \%$ for research, $0.7 \%$ for pedagogical work).

- Increased integration and autonomy for research and training, with the aim of creating a single higher-education and research space.

- Balance enrolment of young people aged 19 to 26 in tertiary education, ensuring at least $60 \%$ coverage of this part of the population and increase proportion of adults in all forms of lifelong learning.

- Increase number of enrolled students completing their studies. The objective is to increase the proportion of the population aged over 15 years eligible for further and higher education from the current $15 \%$ to $25 \%$, and increase the proportion of people enrolling in the first year for the first time who actually complete their degree from $57 \%$ to $75 \%$.

- Facilitate and promote the exchange of knowledge in the higher education-science-economy triangle with the objective of providing the commercial sector with 80 junior researchers per year.

- Improve conditions for study and opportunities for study by young people with special needs. 
Stanka Setnikar Cankar

\section{Decentralisation, Privatisation and Changes in the Financing of} Education in Slovenia: Greater Opportunities for Citizens?

- Promote the internationalisation of higher education and - in addition to effective promotion and control of public and private higher education institution and study programme quality - improve the standing of higher education institutions with the aim of establishing at least one Slovenian university among the best European universities.

- Introduce different criteria for research achievements in different areas, separated according to individual areas of specialisation, but internationally comparable. The objective is to upgrade the general system of criteria and the application of specific ratios among three sets of criteria for each specific purpose.

- Open a "habilitation area " with the objective of increasing the flow of specialists between higher education and research institutions and the economy.

- Encourage the development of less commercially interesting study and research areas. The objective is to adapt the financing of public higher education institutions and concession financing for private higher education institutions offering such programmes (see National Higher Education Programme of the Republic of Slovenia, 2007 2010, p. 5).

\section{Decentralisation and higher education}

Slovenia is one of the most centralised states in the EU, which means decentralisation remains an important issue (Setnikar Cankar, 2002b, 2008).

Irrespective of people's views on economic and non-economic development in the past in Slovenia within the former Yugoslavia, a positive view of the spatially relatively equal development in the 1970s and 1980s is commonly held. Some areas already had the status of less-developed areas at that time. This entitled them to additional funds to accelerate investments in economic and non-economic infrastructure. The development of larger town centres and rural areas was quite balanced, with differences smaller and more acceptable (Setnikar Cankar et al., 2008).

Unfortunately circumstances have changed significantly over the past 17 years, with some larger centres, towns or areas developing at a significant pace; the centralisation of economic development is coinciding with the centralisation of economic power and political influence. The concentration and 
centralisation of capital, jobs and economic and political power are causing major social changes, between social groups, and mainly between a few developing centres and other parts of the country. Dissatisfaction with most matters relating to decisions taken in these major centres (i.e. the capital city) is having a range of undesirable consequences. Reciprocal relations are often harmed, creating mistrust and preventing constructive dialogue. The decisions - which belong, or at least should largely belong, to the realm of independent experts - are immediately attributed to the centralising tendency or to political controllers. The fear of centralisation is often exaggerated in smaller settlements, though justified in part.

While excessive centralisation sooner or later requires decentralisation, effective economic policy requires that powers are transferred up to a higher level. The central government wants to control the economy because of external pressures caused by global competition. The internal movement of goods, services, production and the population can force the government to reduce internal decentralisation.

In Slovenia the question of decentralisation is currently subordinate to the creation of regions as an intermediate level between central government and local communities. In general this takes into account the reallocation of political power, but this is ineffectual without economic and financial power. The creation of regions will make sense if central government transfers some of its powers and financial resources to them at the same time. Experience to date has shown that reducing the existing power of central government is very difficult (Šmidovnik, 2007).

Regions would offer a new form of local autonomy, not yet seen in Slovenia. This means, of course, that there is a complete lack of a self-governing tradition at the regional level.

The issue of whether Slovenia needs another tier of power between central government and municipalities has always been contentious. In 2006, after over a decade of discussions, legislation was passed creating the regions. The government put forward a proposal for 14 regions (Government of the Republic of Slovenia, 2008).

The draft Act on the Transfer of Competences from Central Government to the Regions envisages transferring responsibilities to the regions from 1 January 2009 in the following areas:

- regional development; 


\section{Stanka Setnikar Cankar \\ Decentralisation, Privatisation and Changes in the Financing of Education in Slovenia: Greater Opportunities for Citizens?}

- environmental and spatial planning;

- transport;

- economy;

- agriculture;

- higher education and science;

- education and sport;

- health:

- culture;

- protection against natural and other disasters;

- internal affairs;

- $\quad$ implementing social security, labour and family-related tasks.

There is significant political pressure supporting the idea that if Slovenia has regions they should be as busy as possible, which could affect the quality of public services. At first glance, this devolution of powers seems rational, but in fact it is risky. Regions set up in this way would act as extended arms of the central government (Šmidovnik, 2008).

Regional self-government may only be a facade if there is not an adequate financing system (Vlaj, 2008b). Financing should be organised to encourage regions to be more productive. It seems that according to the government proposal, the regions will only receive a small amount of national taxes, a small portion of income tax revenue, property tax, capitation, and equalisation payments.

Only a reduced number of larger regions would have sufficient human and material resources to carry out their (very extensive) tasks. They would be stronger partners in relations with central government, cross-border links and more successful in acquiring financing from EU funds (Vlaj, 2008a).

All of the concerns regarding the proposed transfer of powers and the number of regions have been repeated in the face of the plan to found seven to ten universities, as written in the National Higher Education Programme 2007-2010. The most critical factors for establishing such a high number of universities and to ensure the quality of higher education are the teachers and material operating conditions.

The National Programme also includes a provision that the number of higher education teachers and collaborators must be increased to improve study conditions, while a high quality rehabilitation of Slovenian higher education 
institutions will make them more attractive for domestic and foreign specialists and students.

A genuine danger is that the introduction of small regions - which would be followed by the establishment of new universities that would fall under their auspices - could only strengthen centralisation.

The idea that greater regional dispersion of higher education providers would improve public service provision is questionable. Just as disputed is the idea that the small size or private status of a university would ensure quality (Šević, 2008). A frequent argument for the establishment of new higher education institutions in Slovenia is the statement that there must be greater competition and choice for future students. Advocates of such statements probably base them on economic theories of people's behaviour, according to which they optimise their decisions in conditions of perfect or as high a level of competition on the market as possible.

\section{Privatisation and higher education}

We advocate the introduction of market principles to the public sector through supporting operational changes in the sense of incorporating elements of enterprise culture and introducing public-private partnerships (Setnikar Cankar, 1993, 2002a, 2008a).

In the economic theory of the operation of a market in private goods, the level of competition has an important impact on consumers' optimal decisionmaking.

The level of competition can be assessed with the following indicators: number of suppliers and consumers, size of suppliers and consumers, market share, entry conditions for the sector, information, homogeneity of the good, and rationality of decision-making by sellers and purchasers.

Perfect or pure competition is defined by a large number of suppliers and consumers, who are as equal as possible in size (measured in number of employers and capital) and market share, who have the same entry conditions to the sector without unnecessary obstacles, with equal access to information needed to make optimal decisions, offering a homogenous good, and rational in their decisions. 


\section{Stanka Setnikar Cankar \\ Decentralisation, Privatisation and Changes in the Financing of Education in Slovenia: Greater Opportunities for Citizens?}

The result of adapting supply and demand under conditions of perfect or pure competition is the optimisation of decision-making by suppliers and consumers. For consumers this means that they can purchase a private good that meets their needs and income such that they pay a price that matches the marginal utility of a good. In other words, private goods are sold too expensively, or acquired to cheaply. Of course, this rule is realised as a long-term tendency with the aid of a market mechanism.

Globalisation has undoubtedly had a positive impact on the competitiveness of private goods markets, which consumers in Slovenia can observe in everyday purchases of items such as food, clothing, white goods, and cars. The evidence is seen in competition in price and/or quality. The consumer pays a lower price for the same quality of product, or receives more or better quality for the same price.

The real world, of course, also has markets with imperfect competition. Imperfect forms of competition include monopolies, where there is just one supplier and many consumers, and oligopolies, which feature a small number of suppliers (from 3 to 5) and a large number of consumers. A monopolist charges a higher price, since it includes the monopoly profit. An oligopolist is also in a position in which it can realise an above average profit.

It seems that the main function of the privatisation and decentralisation of higher education in Slovenia is to increase the number of higher education service providers and offer more choice for consumers.

The question is whether the higher education service market can be treated in the same way as a market for other consumer goods? The answer could only be a conditional affirmative, if one takes the position that education is a private good. In a society in which education is at least partly a public good, in the provision of which consumers (students and their parents) and suppliers (public and private educational organisations) cooperate, as well as political institutions of central or public administration (government, parliament, ministries, municipalities), the elementary mechanism of a market economy is not directly applicable. Only changing some of the factors of perfect competition (larger number of suppliers, changes in market share, undemanding entry conditions) creates 'quasi-competition', which cannot supply the most desirable objective in the provision of a public good such as higher education: a higher quality service. Adopting measures that would introduce other conditions of perfect competition in the public sector field can even have a negative effect. I hope that future higher education policymakers in Slovenia do not think that 
they should have a large number of approximately equal large or small educational institutions due to the positive consequences of competition, even though that would require the break-up of the old universities or the creation of new ones in each of the 14 proposed regions. Support for such an assertion cannot be found in modern economic theory and public sector practice, whether one looks for examples in Europe (from the UK to the Nordic countries), the US, or among the "Asian tigers" such as Singapore.

The public sector is too important to allow public or private organisations of insufficient quality to operate, even if it were only for a short period. It cannot be permitted that students who enrol in programmes offered on the basis of a state concession and successfully complete them, then find on the labour market that although their degree is formally equivalent, in fact it puts them in a poorer position when applying for jobs, promotion or in salary negotiations. Responsibility for a quality public higher education system lies primarily with political institutions of central government and public administration, which define the systemic operating conditions for public service providers. This is determined by the definition and content of the concept of public benefit. Public benefit demands certain activities be defined public services and is an expression of the constitutional requirement that the state protects human rights on its territory and within that framework actively creates conditions in which such rights can be exercised (Čebulj, 2007).

It seems reasonable to emphasise the material aspect of a public service, since it is often confused with public service in the organisational sense (the form of provision). Similarly, the concept of the privatisation of public services is sometimes confused, where often no distinction is made between the privatisation of an activity that is a public service (in which case the consequence of privatisation is that the activity is no longer a public service, but becomes a "regular" activity), and the privatisation of provision of a public service (in which case the activity remains a public service, only the implementation is transferred - e. g. by concession - from the public to the private sphere). The most important public services are based on the human rights defined in the Constitution. The most important "social activities" include public services in the field of social security, healthcare, support for disabled people, child protection and education' (Čebulj, 2007).

1 According to Article 57 of the Slovenian Constitution, primary school education is compulsory and financed from public funds, and the state must ensure that citizens can acquire an adequate education. 
Can we accept in full the idea that students can really be the "best judges"? It is quite simple to indicate that most students follow specific strategies that prevent an "optimal social selection". Given all the deficiencies of the labour market, the characteristic strategy of a student may be shortterm: selecting the easiest way of completing their studies. Another frequent difficulty in central and eastern Europe is that students, probably due to a lack of funds or due to their family situation, most frequently decide to enrol in a higher education programme that is as close to their home as possible ( $\mathrm{Ne}$ mec, 2008).

A non-discriminatory entry system, based on criteria fundamental to the activity, is merely a necessary condition to ensure quality. We support an agreement on minimal conditions for the operation of public or private education institutions that meet EU standards. Every higher education sector in Slovenia can be defined by criteria which must be met to acquire European accreditation. Their minimum value would be sufficient for entry to the sector. An adequate condition for performance of a concession is only achieved with the acquisition of European accreditation, in three to four years. Any educational institution, public or private, that failed to acquire European accreditation would lose its licence. It would then have a one to two year transitional period to fulfil the criteria. This system would simulate the operation of a market mechanism. The threat of losing a licence would require quality work. Acquiring international accreditation would represent a competitive advantage and guarantee of quality for students. Since accreditation is only granted for a limited number of years (five to seven) and has to be renewed, the system also ensures respect for increasing demanding operating conditions.

This means that one of the most demanding tasks in coming years is to ensure high quality higher education, non-discriminatory access to higher education, and reducing the gap in quality between higher education institutions. The quality of the programme and teachers, and of course, the students, is the only criteria that can contribute to improving the public service (Bugarič, 2007).

Some experts may state that students (along with their parents) are the people best placed to decide on the quality of the institution at which they want to study. This would mean there would be no need to establish a state accreditation system to check whether a school or programme has the right to grant a university degree (Maras, 2007). 


\subsection{International Accreditation}

Most, if not all, states in central and eastern Europe, and many other countries, use accreditation as a means of selecting universities entitled to public funding. The general rule is that only programmes with state accreditation are granted public funds: in most states programmes without accreditation are not even run. But let us consider the fact that one can still ask: "Is accreditation really necessary?" Why should anyone have the right to approve or reject a school or its programme?

The justifications for the existing procedures for state accreditation include:

- providing authentication for institutions and programmes;

- functioning as a gateway condition for state financing;

- facilitating access to the profession;

- promoting student and professional mobility;

- in guaranteeing high standards, accreditation offers a sign of excellence and facilitates comparison, marketing and cooperation at a high level; in some cases it is used to protect state higher education systems from supranational and private operators (Daemen et al., 2008).

In addition to some of the reasons given above, the main justification for an international framework of accreditation is the protection of consumer rights and market transparency in an increasingly global, complex and diverse higher education market. Therefore, domestic and international benchmarking of quality assurance procedures (CRE, 2001) is key.

There is another justification for European accreditation which cannot be avoided: Globalisation and the Bologna Declaration, the main objective of which is to build bridges between state university education systems and facilitate student mobility during studies, indicate that international approval of a programme or institution is increasingly important.

Changes have occurred in the socio-economic environment as a consequence of the globalised economy, which have led to changes in the university sector and other education sectors. Despite this, it is difficult to generalise about patterns, trends and models in the development of higher education in European countries, since each country or society may have its own level and speed of development. Various comparative studies on the same theme have reported interesting patterns and trends common throughout European development of higher 
Stanka Setnikar Cankar

Decentralisation, Privatisation and Changes in the Financing of Education in Slovenia: Greater Opportunities for Citizens?

education. Some of the most notable of these are: massification, diversification, privatisation, market orientation, internationalisation, ensuring standards in higher education and the quality of higher education which has led to increased private investment and a fall in public support for higher education, Europeanisation, etc.

Globalisation could deepen current inequalities. Academic systems and institutions, which could once develop within state borders, must now face international competition. Official languages compete with English even within state borders. Domestic academic journals increasingly compete with international publications in state academic systems, and the academics feel the pressure to publish internationally. Developing countries have found themselves in a significantly more difficult position in the new globalised academic system, and find it difficult to compete even with smaller academic systems in wealthier countries. Inequalities in the globalised era are deep and in part even more complex than during colonialism (Altbach, 2008).

Based on pilot study findings, we have ascertained that establishing a national system of external evaluation requires an appropriate set of Europeancompliant quality system rules, the organisation of appropriate training for, and records relating to, evaluators, and effective supervision over the higher education quality provision and quality assurance system (Trunk et al., 2007).

One expects that the accreditation process in Slovenia will largely be used as a regulatory tool. Unfortunately, it permits a considerable amount of subjectivity, and lacks international comparability. This makes accreditation in Slovenia more a tool for competitiveness between new and established schools in efforts to acquire public financing.

\section{Public financing of higher education}

In 2004, the higher education financing system in Slovenia moved away from the concept of payments according to standards and norms, since it was considered too detailed, inflexible, and bureaucratic for the modern organisation and operation of universities and other higher education institutions. An integrated "lump sum" financing of study provision was introduced, which took into account the area of study, the number of enrolled students in a year, and the number of graduates in the past calendar year. This gave higher education institutions greater independence in the allocation of funds and allowed 
them to make more effective use of them. Study-related activities and concession-based higher education institutions are financed under the same conditions (Jaklič, 2008).

The method of public financing for educational institutions can have a major impact on the effectiveness of the institutions and the volume of costs. It is important that education financing offers economic and physical benefits to the individual and to society (Bevc, 2007).

\subsection{Regulations on higher education financing}

Higher education institutions include universities, faculties, art academies, and higher professional schools. The umbrella act is the Higher Education $\mathrm{Act}^{2}$, on the basis of which the Slovenian Government adopted the Decree on Public Financing of Higher Education and other University Member Institutions 2004-2008 ${ }^{3}$.

The Higher Education Act (HEA) regulates the status of higher education institutions and the conditions for provision of higher education services, defines public services in the context of higher education, and governs the method of their financing:

The HEA introduced the integrated (lump sum) financing of study activities. This means that it takes into account areas of study (according to the ISCED classification, Unesco, November 1997), the number of enrolled students, and the number of graduates ${ }^{4}$.

Funds for study activities are provided at the first and second cycle in the national budget fund as joint funds for a university or independent higher education institution (integrally financed), taking into account the area of study, the number of students and graduates from full-time study in the first and second cycle.

Third-cycle study programmes may also be funded from the national budget via a public tender issued by the Ministry of Higher Education, Science and Technology.

2 Official Journal of the Republic of Slovenia, No 119/2006

3 The Slovenian Government defined the consolidated version of the Decree on the Public Financing of Higher Education and other University Member Institutions - 2004-2008 at its 100th regular session, on 7 December 2006.

4 Resolution on the National Higher Education Programme of the Republic of Slovenia 20072010. OGRS, No 94/2007. 


\section{Stanka Setnikar Cankar \\ Decentralisation, Privatisation and Changes in the Financing of Education in Slovenia: Greater Opportunities for Citizens?}

Funds for student's study-related activities are defined by taking into account the number of enrolled students and the value of points defined for each student for each budget year by the minister responsible for higher education.

More detailed provisions on the financing of higher education are defined in accordance with the Higher Education Act and national programme standards $^{\mathbf{5}}$ in the Decree on Public Financing of Higher Education and other University Member Institutions - 2004-2008 ${ }^{6}$ (the Decree).

The Decree was introduced in 2004 and was amended several times, most recently in 2006. It introduced the integrated financing of higher education (Golubič, 2008).

The Decree's main objective is to give higher education institutions greater flexibility and autonomy in managing funds and to create a basis for realising long-term objectives for changes to financing, such as:

- greater responsiveness from higher education institutions to society's needs (social and economic)

- making higher education accessible to all by giving every student the opportunity to complete studies regardless of their social and economic status, and

- providing rational and transparent use of budget funds ${ }^{7}$.

The Decree also regulates the public financing of study activities ${ }^{8}$ and study-related activities ${ }^{9}$, investment, investment maintenance, and development tasks at universities and independent higher education institutions founded by the Republic of Slovenia, and financing tasks of national importance.

5 Most recent national programme: Resolution on the National Higher Education Programme of the Republic of Slovenia 2007-2010. OGRS, No 94/2007.

6 OGRS, Nos 134/03, 72/04, 4/06 and 132/06.

7 The production of an economic model to simulate the effects of changing the tertiary education system, p. 39.

8 Pedagogic and related scientific research, art, and specialist activities of higher education teachers and collaborators and scientists, and library, information, organisational, administrative, and other infrastructure-related activities.

9 Study-related activities of interest to students, defined in an annual programme by the university or independent higher education institution's student council and university sport. 
Decentralisation, Privatisation and Changes in the Financing of Education in Slovenia: Greater Opportunities for Citizens?

Table 1: Strengths and Weaknesses of Decree's Financing

\begin{tabular}{|l|l|}
\hline Strengths & Weaknesses \\
\hline Independence of higher education & $-\quad \begin{array}{l}\text { Distribution of funds by the decree is } \\
\text { based on } 2003 \text { figures }\end{array}$ \\
$-\begin{array}{l}\text { Predictability of financial planning } \\
\text { Funds for university member institu- } \\
\text { tions are divided at the national level }\end{array}$ \\
$\begin{array}{l}\text { The granting of funds is not suffi- } \\
\text { ciently linked to quantitative and quali- } \\
\text { tative demands by the ministry (state) }\end{array}$ \\
\hline
\end{tabular}

Source: Trunk Širca et al., 2007

The largest proportion of total spending on formal education is allocated to primary education: $46 \%$ in 2005 , and $45 \%$ in 2006 . Primary education is followed by secondary education with $24 \%$ in 2005 and $25 \%$ in 2006, tertiary education with $22 \%$ in 2005 and 2006 , and pre-school education with $8 \%$ in 2005 and $9 \%$ in 2006. In 2005 and 2006 the largest proportion of total public spending on formal education was direct spending for educational institutions (91\%).

Nominal public funds for tertiary education (undergraduate, graduate and other higher education) increased according to the Ministry of Finance (Budget Realisation 2001 - 2006). From 2005 to 2006 it increased by 8.84\%, while from 2001 to 2006 it increased as much as $58.21 \%$. Over that period funds for study assistance also increased, by $26.61 \%$, but from 2005 to 2006 it rose just $0.47 \%$.

The proportion of GDP dedicated to overall spending on education is relatively high, but at the tertiary level it diverges from the EU figure in terms of the structure of spending on education and amount per participant.

In Slovenia the proportion of GDP allocated to total public spending on education in 2003 was $6.02 \%(0.56 \%$ on pre-school education, $2.66 \%$ on primary education, $1,46 \%$ on secondary education and $1.34 \%$ on tertiary education), where $90.3 \%$ of public spending was allocated directly to educational institutions, and $9.7 \%$ on transfers to households and private institutions (EU25 average: 94.4\% - 5,6\%; EU-15 average: 94\% - 6\%; Denmark: 80.4\% - 


\section{Stanka Setnikar Cankar \\ Decentralisation, Privatisation and Changes in the Financing of Education in Slovenia: Greater Opportunities for Citizens?}

19.6\%). In 2004 the proportion fell to 5.96\% of GDP. Most European countries allocated 4 to $6 \%$ of GDP to education, the EU-25 average is $5.21 \%$, with Nordic countries in particular (Denmark, Sweden, Norway) exceeding the average with figures between 7 and $8 \%$ of GDP.

Table 2: Slovenian Budgets from 2006 to 2009 - ratio of funds for tertiary education to funds for study activities

\begin{tabular}{|c|c|c|c|}
\hline $\begin{array}{c}\text { Budget } \\
\text { year }\end{array}$ & $\begin{array}{c}\text { Budget funds for tertiary edu- } \\
\text { cation in EURO }\end{array}$ & $\begin{array}{c}\text { Funds for study ac- } \\
\text { tivities in EURO }\end{array}$ & Ratio (\%) \\
\hline 2006 & 216135704 & 197019546 & $91.16 \%$ \\
\hline 2007 & 236583722 & 206117961 & $87.12 \%$ \\
\hline 2008 & 255442039 & 213253051 & $83.48 \%$ \\
\hline 2009 & 284458166 & 229156379 & $80.56 \%$ \\
\hline
\end{tabular}

Source: Ministry of Finance, 2008

It is important to emphasise that in Slovenia public spending on pre-school and primary school education increased between 2000 and 2004, which represent $53.5 \%$ of all public spending on education. In Slovenia tertiary education represented only $22.2 \%$ of public spending. In the EU-25 the highest increase in spending over the period has been on secondary and tertiary education (Kamnar, 2007).

The 2006 employment data indicates a growth in employment in the further and higher education sector, from which one may conclude that we are at the start of a structural move towards strengthening tertiary education. The growth in employment is largely the consequence of a significant number of colleges and higher education institutions and the renewal and introduction of new study programmes, which has not yet been followed by an appropriate increase in public spending on tertiary education. Slovenia's annual spending 
on educational institutions per participant for all levels of education is typical for EU states, while in 2003 Slovenia was well behind the EU in terms of the amount of spending per student in tertiary education (see Development Report 2007, pp. $118-119$ ).

The lowest figure was for the number of students per teaching staff member. The number of students per teaching staff member is frequently used as a measure of quality, where a lower number generally means a higher chance of better quality pedagogical process. The number of students per staff member is improving, but Slovenia remains behind most European countries. In the 2005/2006 academic year this figure was 21.3 students per teaching staff member. The most recent data for other European countries, available for the 2003/2004 academic year, indicate that only Greece (28.1) and Italy (21.6) have a higher figure than Slovenia (21.5). The best figure for that year was for Sweden with 9 students per teaching staff member (see Development Report 2007, pp. $114-115)$

\section{Conclusion}

The conviction that a state can only "force" higher education institutions to function more effectively through greater intervention in financing, recruitment and human resources, and decision-making is erroneous. The experience of developed countries (Daemen, 2008) indicates that governments create transparent systemic conditions, ensure their stability, and establish a sound and independent regulatory environment in charge of implementing this framework. The system gives service providers operational autonomy to make their own decisions on their strategy within the set "rules of the game". The operational autonomy of universities is an essential condition for a more creative search for competitive advantage, which is not based on reducing costs by lowering service quality. The idea of strategic centralisation and operational autonomy is at least 12 years old (Setnikar Cankar, 1993, 2004). However, it seems that Slovenia still has difficulty introducing it to public sector practice.

The question is often placed in relation to the provision of public services of whether and to what extent a country can exclude or limit free economic initiative, as guaranteed by Article 74 of the Constitution ${ }^{10}$. The issue of freedom

10 This right is one of the rights laid down in the Constitutional chapter on economic and social conditions, which have the same level of protection as human rights. 
Stanka Setnikar Cankar

Decentralisation, Privatisation and Changes in the Financing of Education in Slovenia: Greater Opportunities for Citizens?

of economic initiative is placed from two points of view. Firstly, from the point of view of restricting competition by establishing a (at least partial) monopoly when providing a public service. The other aspect is from the point of view of prescribing special conditions for the performance of other (economic) activities, which must not harm the goods, which are protected by the public service regime (Čebulj, 2007).

The salary system in the public sector is the most recent example of an intervention in public universities since they became financed from public resources. The founder has another, more effective mechanism for control. "Lump-sum" financing is therefore much more compatible with the idea of higher education autonomy. The abolition of more or less autonomous salary systems adapted to individual groups of "civil officials" with very different systems of promotion, has been just one of the negative consequences. Instead of autonomous systems, a rigid system was introduced which will have to be continually adjusted, with each correction sure to lead to new arguments between and within professional groups (Mencinger, 2008).

Attention should also be drawn to a further inequality in the system of public and private concessions in higher education. Although all programme implementers will acquire budget funds, the restrictions and rules of the new salary system will only apply to employees in public universities. We would point out the unequal opportunities for employers to reward above-average quality work by their employees or to acquire better implementers. For some time there has been an open fight for finances, programme implementers and students, while working conditions differ for public and private implementers due to systemic factors.

The key condition for an increase in the quality of higher education in Slovenia is regulation, via the provision of a necessary and adequate operating conditions. Without independent and high quality regulation there is no guarantee of achieving the desired level of quality. In these conditions, liberalisation and increasing competition could lead to the reallocation of monopolies and oligopolies, and to reducing rather than improving quality. We meet numerous bodies and agencies, which are largely "toothless" tigers, which only superficially resemble established regulators in more developed countries (Bugarič, 2007).

Slovenia's small size, where it is difficult to ensure the independence and objectivity of regulators, may be overcome in combination with international accreditation. We are aware that some international accreditation organisations 
also have lax criteria, based primarily on paying for procedures, although this is a more common practice outside Europe. We therefore support accreditation organisations which are also recognised by developed European countries. In the field of public administration, for example, EAPAA accreditation is recognised as a nationally valid accreditation by the Netherlands.

Stanka Setnikar Cankar is Professor of Basic Economics, Public Sector Economics and Public Choice at the Faculty of Administration (University of Ljubljana). She has been a full professor since 2004. Between 1999-2003 she carried out two mandates as Dean of the School of Public Administration and on its transformation into the Faculty of Public Administration in 2003, she became the first Dean of the Faculty (2003-2005). Since 2005 she has been a Vice-Dean for International Relations. Professor Setnikar Cankar's research interest focuses on an interdisciplinary field which covers public sector reform and health care, evaluation of effectiveness and efficiency in public administration, analysis of the impact of state administration and regulations on the economy and the current situation and prospects for self-governance in Slovenia.

\section{Bibliography}

- $\quad$ Altbach, P.G. (2008): Globalization and Forces for Change in Higher Education, The 50th Issue of International Higher Education, London.

- Bevc, M. (2007): Sistem financiranja visokega šolstva v Sloveniji (Ljubljana, Inštitut za ekonmska raziskovanja)

- Bilten javnih financ, (2008), Ministrstvo za finance, Ljubljana.

- Bugarič, B. (2007): Reforma visokega šolstva v Sloveniji: Kako naprej? Dnevi slovenske uprave, Fakulteta za upravo, Ljubljana.

- $\quad$ CRE (Complementary Measures for Higher Education) (2001): Towards Accreditation schemes for Higher Education in Europe? http://siteresources.worldbank.org/INTAFRREGTOPTEIA/Resources/Towards_Accr editation_for_European_Higher_Education.pdf 20.4.2008

- Čebulj, J. (2007), : Ustavnopravni vidiki privatizacije javnih služb, Dnevi slovenske uprave, Fakulteta za upravo, Ljubljana.

- Daemen, H., van der Krogt, T. (2008): Four Functions of International Accreditation: The case of EAPAA and Public Administration in the Netherlands. NISPACee, 2008. (Forthcoming), Bratislava. 


\section{Stanka Setnikar Cankar}

\section{Decentralisation, Privatisation and Changes in the Financing of Education in Slovenia: Greater Opportunities for Citizens?}

- Golubović, B. (2008): Financiranje javnega visokošolskega izobraževanja v Sloveniji in na Nizozemskem, seminarska naloga, Fakulteta za upravo, Ljubljana.

- Jaklič, K. (2008): Analiza izbranih vidikov poslovanja Ekonomske fakultete Univerze v Ljubljani za obdobje 2003-2007, seminarska naloga, Fakulteta za upravo, Ljubljana.

- Kamnar, H. (2007): Javno financiranje visokega šolstva v Sloveniji, Univerza v Ljubljani, Ljubljana.

- Košmrlj, K., Trunk Širca, N., Faganel, A., Rodman, K. (2007): Pilotne institucionalne zunanje evalvacije slovenskih visokošolskih zavodov v letu 2006, Dnevi slovenske uprave, Fakulteta za upravo Ljubljana.

- Maras, M. (2007): National Quality Report: University Lifelong Learning in Slovenia. http://apu.cfp.upv.es/repositorio-comunidad/282.Rep/SI_ENedNQR.doc 20.5.2008)

- Mencinger, J. (2008): Sistem pravičnih plač $v$ javnem sektorju: 1 profesor = 0,63 poslanca $=1,03$ sodnika $=$ ? vojaka, Delo, 29.07.2008, Ljubljana

- Ministrstvo za visoko šolstvo, znanost in tehnologijo Slovenije, 2008: Podatki o vpisanih dodiplomskih študentih $v$ Sloveniji

- Nemec, J. (2008): Accreditation processes in Slovakia and neighbouring countries in Central Europe: current problems and possible improvements. NISPACee, 2008. (Forthcoming).

- Setnikar-Cankar, S. (1993), Podjetništvo kot dejavnik gospodarskega razvoja. Doktorska disertacija, Ekonomska fakulteta, Ljubljana.

- Setnikar-Cankar, S., Andoljšek, Ž. (2004): Mogučnosti merenja uspešnosti državne uprave u Sloveniji, Fakultet organizacionih nauka, Beograd.

- Setnikar-Cankar, S., Pevcin P., (2002a): Public Administration Reform Through the Abolishment of Administrative Barriers to Investment - Fostering the Internationalisation of the Slovenian Economy, 10th EADI international conference, Fakulteta za družbene vede, Ljubljana.

- Setnikar-Cankar, S. (2002b): Fiscal Centralisation and Decentralisation in Slovenia, The Eighth International Conference. Theoretical and practical aspects of public finance ,Faculty of Economics, Prague.

- $\quad$ Setnikar-Cankar, S., Klun, M., Aristovnik, A., Pevcin, P., Andoljšek, Ž. (2008a): Ekonomika javnega sektorja s proračunskim financiranjem, Fakulteta za upravo, Ljubljana.

- Setnikar-Cankar, S. (2008b): Slovenian Approach to Regionalisation and Decentralisation: Some Open Questions, University Press, Greenwich, Fakulteta za upravo, Ljubljana.

- Statistični urad Republike Slovenije, http://www.stat.si/eng/tema_demografsko_izobrazevanje.asp 5.5.2008.

- $\quad$ Šević, Ž. (2008): The Local Government in a Decentralising State: The Case of the UK, Greenwich, University Press, Ljubljana, Fakulteta za upravo. 


\section{Decentralisation, Privatisation and Changes in the Financing of} Education in Slovenia: Greater Opportunities for Citizens?

- Šmidovnik, J. (2007): Vlada očitno meni, da politična realnost prevlada nad vsako argumentacijo stroke. V: Mladina, 23.6.2007, Ljubljana.

- S Šmidovnik, J. (2008): Premajhne pokrajine ne morejo izvajati svojih pristojnosti, Objektiv. V: Dnevnik, 9. 2. 2008, Ljubljana.

- Trunk Širca, N., Kodrič, B., Strašek, R., Marjetič, D. (2007): Izdelava ekonomskega modela za simulacijo učinkov sprememb sistema financiranja terciarnega izobraževanja, Fakulteta za management, Koper.

- Vlada RS, Služba Vlade RS za lokalno samoupravo in regionalno politiko. Predlagana pokrajinska delitev. Http://www.svlr.gov.si/.

- fileadmin/svlsrp.gov.si/pageuploads/lok-sam05/pokrajine/pokr-2007/Pokrajine17.6.2008, Ljubljana.

- Vlaj, S. (2008a) : Regionalisation of the Republic of Slovenia, Uprava VI/1, marec 2008, Ljubljana.

- Vlaj, S. (2008b), Deli in vladaj. V: Delo, 11.4.2008. Ljubljana. 
Stanka Setnikar Cankar

Decentralisation, Privatisation and Changes in the Financing of

Education in Slovenia: Greater Opportunities for Citizens?

POVZETEK

\section{DECENTRALIZACIJA, PRIVATIZACIJA IN SPREMEMBE FINANCIRANJA VISOKEGA ŠOLSTVA V SLOVENIJI: BOLJŠE MOŽNOSTI ZA DRŽAVLJANE?}

Prispevek obravnava decentralizacijo, privatizacijo in javno financiranje visokega šolstva $v$ Sloveniji. Visoko šolstvo $v$ Sloveniji so po mnenju avtorice $v$ zadnjem obdobju zaznamovali predvsem spremenjena visokošolska zakonodaja, uveljavitev novega, integralnega sistema financiranja, bolonjska reforma študijskih programov in ustanavljanje zasebnih visokošolskih zavodov. V članku izhaja iz dejstva, da slovenski visokošolski zavodi še ne dosegajo kakovosti najboljših evropskih univerz, in so že zaradi tega po njenem mnenju spremembe visokega šolstva v Sloveniji nujne, saj bi izboljšana kakovost lahko pomembno prispevala $k$ večji uspešnosti Slovenije $v$ mednarodnem okolju. Tudi zato bi morala biti razprava o prihodnjem razvoju visokega šolstva $v$ Sloveniji ena od osrednjih razvojnih tem. Avtorica $v$ članku ne izgublja časa in prostora $z$ opisovanjem in presojanjem preteklih odločitev, ki so pripeljale do sedanjega stanja, temveč se osredotoča predvsem na prihodnji razvoj visokega šolstva v Sloveniji $v$ pogojih globalizacije in vedno bolj tržno usmerjenega okolja Evropske unije.

Avtorica v članku najprej predstavi Nacionalni program visokega šolstva Republike Slovenije za obdobje 2007-2010 ter ključne usmeritve in cilje razvoja strne $v$ naslednjih točkah:

1. Povečati število visokošolskih zavodov v Sloveniji in doseči boljšo regionalno pokritost $s$ posameznimi oddelki oziroma programi $v$ vseh slovenskih regijah, pri čemer je cilj 7 do 10 univerz oziroma visokošolskih in inovacijskih središč v Sloveniji.

2. Ob sedanjem gibanju financiranja povečati sredstva za visokošolsko izobraževanje in raziskovalno delo, pri čemer je cilj skupno $5 \%$ BDP, od tega $2,3 \%$ iz proračuna ( $1 \%$ za raziskave, $1,3 \%$ za pedagoški del) in $2,7 \%$ iz okolja ( $2 \%$ za raziskave, $0,7 \%$ za pedagoški del).

3. Zagotoviti večje povezovanje in avtonomijo raziskovalne in izobraževalne dejavnosti s ciljem ustvarjanja enotnega visokošolskoraziskovalnega prostora. 
4. Uravnotežiti vpis mladih med 19. in 26. letom v terciarnem izobraževanju in zagotavljati vsaj 60 -odstotno zajetje tega dela populacije ter povečati delež odraslih v vseh oblikah vseživljenjskega učenja.

5. Povečati število diplomantov glede na število vpisanih študentov. Cilj je povečati delež prebivalstva starejšega od 15 let, vključljivega $\checkmark$ visokošolsko izobraževanje s sedanjih $15 \%$ na $25 \%$, ter povečati razmerje $z$ obstoječih 57 na vsaj $75 \%$ diplomantov glede na prvi vpis študentov $v$ prvi letnik.

6. Pospešiti in pospeševati izmenjave znanja $v$ trikotniku visoko šolstvo-znanost-gospodarstvo s ciljem zagotavljati 80 mladih raziskovalcev letno za gospodarstvo.

7. Izboljšati razmere za študij ter možnosti za študij mladih s posebnimi potrebami.

8. Spodbujati internacionalizacijo visokega šolstva in s tem, poleg učinkovitega spodbujanja ter nadzora kakovosti javnih in zasebnih visokošolskih zavodov ter študijskih programov, izboljšati uveljavljenost visokošolskih zavodov s ciljem uvrstitve vsaj ene od slovenskih univerz med najboljše evropske univerze.

9. Uvesti različna merila za raziskovalne dosežke na različnih področjih, ločena po posameznih strokah, a mednarodno primerljiva. Cilj je izpopolnitev splošnejšega sistema meril in uporaba posebnih razmerij med tremi vrstami meril za vsak poseben namen.

10. Odpreti habilitacijski prostor s ciljem povečanja pretoka strokovnjakov med visokošolskimi in raziskovalnimi zavodi ter gospodarstvom.

11. Spodbujati razvoj komercialno manj zanimivih študijskih področij in raziskav. Cilj je ustrezna prilagoditev meril financiranja javnih visokošolskih zavodov in koncesijsko financiranje zasebnih visokošolskih zavodov, ki takšne programe izvajajo (glej Nacionalni program visokega šolstva RS 2007-2010, str. 5).

Na podlagi ključnih usmeritev in ciljev nacionalnega programa visokega šolstva se avtorica nadalje osredotoči na problematiko (de)centralizacije, privatizacije in financiranje visokega šolstva v Sloveniji.

Meni, da je zgrešeno prepričanje, da lahko država z večjimi posegi v financiranje, kadrovanje in odločanje na visokošolskih zavodih, le-te "prisili « k bolj učinkovitemu delu. Izkušnje iz razvitih držav kažejo, da vlade ustvarijo pregledne sistemske pogoje, zagotovijo njihovo stabilnost, vzpostavijo 
Stanka Setnikar Cankar

Decentralisation, Privatisation and Changes in the Financing of Education in Slovenia: Greater Opportunities for Citizens?

dobrega in neodvisnega regulatorja, ki skrbi za implementacijo takšnega okvira. Ponudnikom storitev tak sistem pušča operativno avtonomijo, da se sami odločajo o svoji strategiji znotraj tako oblikovanih pravil igre. Operativna avtonomija univerz je bistven pogoj za večjo kreativno iskanje konkurenčnih prednosti, ki pa ne temeljijo na zmanjševanju stroškov zaradi nižje kakovosti storitev.

V Sloveniji je pred kratkim uvedeni sistem plač $v$ javnem sektorju zadnji primer posega $v$ javne univerze, ki dokazuje rigidnost sistema in hkrati opozarja na neenakosti $v$ sistemu javnega in zasebnega koncesioniranega visokega šolstva. Čeprav bodo vsi izvajalci programov pridobili proračunska sredstva, omejitve in pravila novega plačnega sistema veljajo samo za zaposlene na javnih univerzah. $S$ tem pa so delodajalci postavljeni $v$ neenak položaj, da nagradijo nadpovprečno kakovostno delo zaposlenih ali da pridobijo najboljše izvajalce. Že nekaj časa je odprta tekma za finančna sredstva, izvajalce programov in študente, pogoji delovanja za javne in zasebne izvajalce pa se razlikujejo zaradi sistemskih ukrepov.

Ključni pogoj za povečanje kakovosti visokega šolstva v Sloveniji bi bila regulacija preko zagotavljanja potrebnega in zadostnega pogoja za delovanje, vendar bi bilo zaradi majhnosti Slovenije težko zagotoviti neodvisnost in objektivnost regulatorjev. Avtorica meni, da bi jo lahko presegli s kombinacijo pod pogoji mednarodne akreditacije. Večina držav, če že ne vse iz osrednje in vzhodne Evrope, in precej drugih uporablja mednarodno akreditacijo kot način izbiranja univerz, ki so upravičene do javnih sredstev. Prav tako tudi globalizacija in Bolonjska deklaracija, katere glavni cilj je premostitev državnih sistemov univerzitetne izobrazbe in pomoč študentom pri mobilnosti med študijem, kažeta, da je mednarodna potrditev programa ali zavoda vse pomembnejša. Tem vodilom in usmeritvam bi morala slediti tudi finančna sredstva. Namreč sistem financiranja visokega šolstva se je v Sloveniji v letu 2004 odmaknil od koncepta plačil po standardih in normativih, ker je bil za sodobno organizacijo in delovanje univerz ter drugih visokošolskih zavodov preveč razdrobljen, neprilagodljiv in preveč administrativen. Uvedeno je bilo integralno (»lump sum«) financiranje študijske dejavnosti, in sicer ob upoštevanju študijskega področja, števila vpisanih študentov $v$ študijskem letu in števila diplomantov $v$ preteklem koledarskem letu. Ni pa mogoče prezreti dejstva, da je $v$ zadnjih letih zaznati trend relativnega upada javnih finančnih sredstev za terciarno izobraževanje. Delež celotnih izdatkov za izobraževanje je znotraj BDP v Sloveniji razmeroma visok, a na terciarni ravni odstopa od EU glede na strukturo porabe izdatkov za izobraževanje in višino le-teh na udeleženca. 
V Sloveniji je delež celotnih javnih izdatkov za izobraževanje znotraj BDP v letu 2003 znašal 6,02 \% (0,56 \% predšolsko izobraževanje, 2,66 \% osnovnošolsko izobraževanje, 1,46 \% srednješolsko izobraževanje in 1,34 \% terciarno izobraževanje), pri čemer je bilo $90,3 \%$ javnih izdatkov namenjenih neposredno za izobraževalne ustanove, $9,7 \%$ pa za transferje gospodinjstvom in zasebnim institucijam (povprečje EU-25: 94,4 \% proti 5,6 \%; povprečje EU-15: $94 \%$ proti $6 \%$; Danska: $80,4 \%$ proti 19,6\%). V letu 2004 se je delež znižal na 5,96 \% BDP. Večina evropskih držav nameni za izobraževanje med 4 in $6 \%$ BDP, EU-25 $\checkmark$ povprečju 5,21 \%; to povprečje presegajo zlasti skandinavske države (Danska, Švedska, Norveška) z nad 7-8 \% BDP. Pri tem je pomembno poudariti, da so se v Sloveniji $v$ obdobju 2000-2004 najbolj povečali javni izdatki za predšolsko in osnovnošolsko izobraževanje, ki v strukturi javnih izdatkov za izobraževanje predstavljajo kar 53,5 \%. Terciarno izobraževanje v Sloveniji predstavlja le 22,2 \% javnih izdatkov.

$\mathrm{Na}$ koncu avtorica izpostavi še eno slabost na ravni terciarnega izobraževanja v Sloveniji - razmerje med številom študentov in številom pedagoškega osebja. Razmerje med številom študentov in številom pedagogov se pogosto uporablja kot merilo kakovosti, pri čemer nižje razmerje načeloma pomeni večjo možnost za kakovostnejši pedagoški proces. Razmerje med številom študentov in številom pedagoškega osebja se izboljšuje, a še vedno zaostajamo za večino drugih evropskih držav. $V$ študijskem letu 2005/2006 je to razmerje znašalo 21,3 študenta na enega pedagoga. Zadnji podatki za ostale evropske države, ki so na voljo za študijsko leto 2003/2004, kažejo, da sta imeli višji delež od Slovenije $(21,5)$ le Grčija $(28,1)$ in Italija $(21,6)$. Najboljše razmerje za navedeno leto izkazuje Švedska, in sicer 9 študentov na zaposlenega pedagoga. 